\title{
Hypospadias in spinal cord injury: association with indwelling catheter drainage and disturbance of behavior: a report of three cases
}

\author{
Ö Taşoğlu, M Doğan Aslan, D Yenigün, S Özbudak Demir, V Binay Safer and N Özgirgin
}

Study design: Case series.

Objective: To present three cases of paraplegic patients with hypospadias and psychiatric comorbidities.

Setting: Ankara Physical Medicine and Rehabilitation Training and Research Hospital, Ankara, Turkey.

Cases: Three spinal cord injured male patients with hypospadias are presented. All three patients had a history of psychiatric disorders that is thought to be a precipitating factor.

Conclusion: This is the first report in the literature of three cases of hypospadias associated with indwelling catheter drainage and behavioral disturbance.

Spinal Cord (2015) 53, S1-S2; doi:10.1038/sc.2014.177

\section{INTRODUCTION}

Urological complications in spinal cord injured patients are frequent, reduce the quality of life and if managed improperly may lead to catastrophic consequences. Iatrogenic hypospadias, first described by Barnes-Snow et al. ${ }^{1}$ in 1985 , is a rare entity that is caused by the downward pressure of the catheter on the urethra giving way to tissue ischemia and necrosis. Here are three cases of hypospadias associated with indwelling foley catheter use and with behavioral disturbances.

\section{CASE 1}

A 22-year-old paraplegic male, who had sustained a spinal cord injury due to a motor vehicle accident when he was 9 years old, was admitted to our rehabilitation center. His American Spinal Injury Association (ASIA) impairment scale (AIS) score was T2 ASIA A. He has been using an indwelling catheter for 13 years. Urogenital examination revealed an $\sim 2.5 \times 4 \mathrm{~cm}$ skin defect on the ventral aspect of the distal penil shaft. The urethral mucosa was exposed along the length of the skin defect (Figure 1). There was no history of infection or discomfort around the penis, nor did he have diabetes (starving blood glucose (SBG): $70 \mathrm{mg} \mathrm{dl}^{-1}$ ). He declared that he realized the defect 2 or 3 years after the accident. Initially, folate deficiency was taken into account owing to the fact that folate levels are of particular importance for midline dehissance, but our clinical decision has been diverted from it upon the normal folate $\left(4.8 \mathrm{ng} \mathrm{ml}^{-1}(3-25)\right)$, hemoglobin ( $\mathrm{Hb})\left(15.4 \mathrm{~g} \mathrm{dl}^{-1}(12.2-18.1)\right)$ and mean corpuscular volume (MCV) (90.4 fl (70-99)) levels. On the other hand malnutrition was also ruled out according to the physical and laboratory examinations. On detailed questioning, a history of psychiatric problems like self mutilation (stubbing out cigarettes on his legs and arms) was disclosed. Alcohol or substance abuse was also examined but he declared that he was a social drinker and used to smoke hash only two times a year. Urodynamic evaluation was consistent with detrussor hyperactivity and markedly decreased bladder capacity. Trospium chloride, $2 \times 30 \mathrm{mg}$ was prescribed. After consultation with the urology department, a suprapubic catheter was recommended and after discharge, an orthotopic neobladder and reconstruction of the urethra was performed.

\section{CASE 2}

A 49-year-old male patient, with a history of failed spinal stenosis surgery 6 months ago, was admitted to our center. He had an AIS score of C7 ASIA B and was using an indwelling catheter. The urogenital examination yielded an acute exudative leison and $2 \times 1 \mathrm{~cm}$ skin defect on the ventral aspect of the penis, of which the patient was unaware. The laboratory testing excluded folate deficiency and diabetes (folate: $3.4 \mathrm{ng} \mathrm{ml}^{-1}$ (3-25), $\mathrm{Hb}: 14.6 \mathrm{~g} \mathrm{dl}^{-1}$ (12.2-18.1), MCV: $82.8 \mathrm{fl}$ (70-99) and SBG: $\left.80 \mathrm{mg} \mathrm{dl}^{-1}(70-110)\right)$ and he was not malnutritioned either. There was a history of suicide attempt and a diagnosis of affective disorder. Psychiatric consultation also revealed out a history of alcoholism in the past, but he was no longer an active drinker. He was initiated on ketiapin fumarate $1 \times 25 \mathrm{mg}$ and duloxetine $1 \times 30 \mathrm{mg}$. The penile lesion was treated by fixation of the catheter to the abdomen and proper medical dressing. The urodynamic evaluation revealed detrussor hyperreflexia and external sphincter dyssynergia with a bladder capacity of $300 \mathrm{ml}$. Oxybutynin $3 \times 5 \mathrm{mg}$ was started. After consultation with the urology department, a suprapubic catheter was recommended. The patient wanted to appeal to another medical center for the urological evaluation and was discharged of his own accord. 


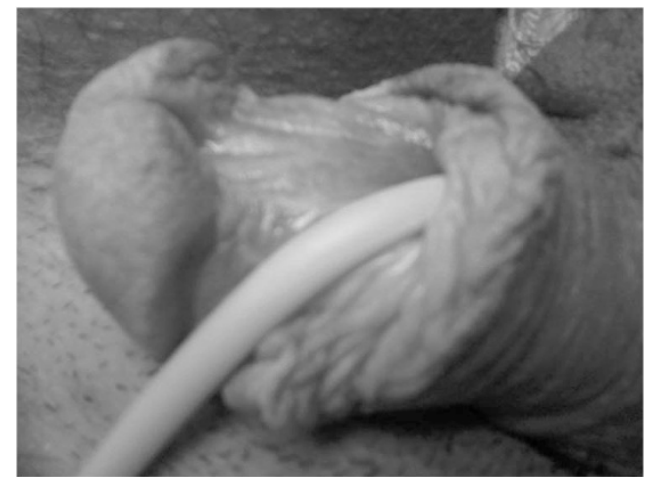

Figure 1 The penile skin defect of case 1.

\section{CASE 3}

A 24-year-old male with spinal cord injury due to diving into shallow water 7 years ago, was admitted for inpatient rehabilitation. His past medical history comprised that he was recommended to perform clean intermittent catheterization but failed to continue and switched to indwelling catheter 3 years ago. His AIS score was C5 ASIA B. On urogenital examination a skin defect of $2 \times 1 \mathrm{~cm}$ on the ventrolateral aspect of the penis was detected. Folate deficiency, diabetes and malnutrition were ruled out by normal physical examination and laboratory tests (folate: $7.9 \mathrm{ng} \mathrm{ml}^{-1}$ (3-25), $\mathrm{Hb}$ : $14.8 \mathrm{~g} \mathrm{dl}^{-1}$ (12.2-18.1), MCV: $86.3 \mathrm{fl}$ (70-99) and SBG: $88 \mathrm{mg} \mathrm{dl}^{-1}$ (70-110)). Because of the depressive mood and suicide ideation, the patient was also consulted with psychiatry department and sertraline $1 \times 50 \mathrm{mg}$ was prescribed with a diagnosis of depression. There was no history of substance abuse. Urodynamic evaluation revealed hyperreflex detrussor with 100-ml bladder capacity. Oxybutynin $3 \times 5 \mathrm{mg}$ was started and again a suprapubic catheter was recommended until discharge. The patient refused to apply to urology department after discharge.

\section{DISCUSSION}

In spinal cord injured patients, genitourinary trauma is as common as urinary tract infections. The most frequent forms are urethral bleeding, false passage, meatal stenosis, urethral stricture, abscess, fistula or diverticulum, ${ }^{2}$ but hypospadias is very rare. ${ }^{3,4}$ In the literature a coincidence of hypospadias and schizophrenia has been reported. ${ }^{5}$ However, ours is the first report where three cases of hypospadias with concurrent psychiatric comorbidities are presented. Probably fluctuations in mood and decreased self-care and attention as a result of psychiatric illnesses led up to this unfortunate situation.

We conclude that it is better to prefer clean intermittant catheterization instead of indwelling Foley catheters as far as possible especially if there is a psychiatric background. When necessary, indwelling catheters should be fixated to the lower abdominal wall ${ }^{3}$ and patients and their caregivers should be informed clearly about the potential complications.

\section{CONFLICT OF INTEREST}

The authors declare no conflict of interest.

\section{DISCLAIMER}

We would like to undertake that the above-mentioned manuscript has not been published elsewhere, accepted for publication elsewhere or under editorial review for publication elsewhere. We submit this article with the approval of all authors.

1 Barnes-Snow E, Luchi RJ, Doig R. Penile laceration from a Foley catheter. J Am Geriatric Soc 1985; 33: 712-714.

2 Webb R, Lawson A, Neal D. Clean intermittent self-catheterization in 172 adults. $\mathrm{Br} \mathrm{J}$ Urol 1990; 65: 20-23.

3 Madersbacher H, Wyndaele JJ, Igawa Y, Chancellor M, Chartier-Kastler E, Kovindha A. Conservative management in neuropathic urinary incontinence. In: Abrams P, Khoury S, Wein A (eds). Incontinence., 2nd edn, Health Publication: Plymouth, UK, 2002, pp 697-754.

4 Bycroft J, Hamid R, Shah PJ. Penile erosion in spinal cord injury-an important lesson. Spinal Cord 2003; 41: 643-644.

5 Montagne A, Loche CM, Bedoiseau M. Longitudinal division of the penis caused by an indwelling urinary catheter in a paraplegic patient. Ann Urol (Paris) 1994; 28 : 270-273. 